\title{
DEVELOPMENT LEARNING CYCLE 5E MODULE INTEGRATED WITH SCIENCE, TECHNOLOGY, ENGINEERING, AND MATHEMATICS (STEM) IN THERMOCHEMISTRY
}

\author{
Nirmala Chayati, Mohammad Masykuri, and Suryadi Budi Utomo \\ Postgraduate Program of Chemistry Education, Faculty of Teacher Training and Education, \\ Universitas Sebelas Maret, \\ Jl. Ir. Sutami No. 36A, Surakarta, Central Java 57126, Indonesia \\ *Correspondence: email : mmasykuri@staff.uns.ac.id
}

Received: January 10, 2020

Accepted: December 22, 2020

Online Published: December 31, 2020

DOI : 10.20961/jkpk.v5i3.38938

\section{ABSTRACT}

The success of the learning process is something that needs to be considered in $21^{\text {st }}$-century learning. One of the successes in teaching and learning uses appropriate learning models. One of the $21^{\text {st }}$-century learning models is the $5 \mathrm{E}$ Learning Cycle integrated with Science, Technology, Engineering, and Mathematics (STEM). This learning model encourages student activities in the teaching and learning process, with the encouragement of student activities, students' science process skills will grow. Science process skill is one of skill that student must have in $21^{\text {st }}$-century learning. One effort to encourage students' process skills is to use a virtual laboratory. This research aims to develop a 5E Learning Cycle module integrated with STEM and is equipped using a virtual laboratory (www.chemcollective.org) on thermochemistry material. This study's subjects were students of class XI of state high schools in the city of Kediri. This research is a Research and Development $(R \& D)$. The data collected through interview, observation, and questionnaires. The results of this study are: students need a teaching material that can drive the student achievement of the teaching and learning process in the $21^{\text {st }}$ century in thermochemistry material; module validity which is declared valid by a severe expert $(v=0.89)$; The module developed shows effective results seen from the learning outcome on thermochemistry material and the module can foster science process skill.

Keywords: 5E Learning cycle, science process skill, STEM, student achievement, teaching material

\section{INTRODUCTION}

Teaching material is one of the students' needs and must be owned by students [1]. Teaching materials that are usually owned by students have printed teaching materials. Students can use various kinds of printed teaching materials in the teaching and learning process, including handouts, books, modules, student work-sheets (LKS), brochures, posters, and leaflets [2].
The module is a book written to study independently with or without a teacher's guidance [3] because the module is a printed teaching material that is systematically arranged. Modules are arranged in one unit used in the teaching-learning process. Modules are arranged from the objectives, topics, subject matter, the teacher's role, learning tools and resources, learning activities, worksheets, and student evaluation [4]. So with these charac- 
teristics, the teacher can act as a facilitator only. The developed modules are arranged in detail and interesting to analyze from content, language and presentation. Also, to attract students in the teaching and learning process, this module uses the Learning Cycle $5 \mathrm{E}$ learning model integrated with Science, Technology, Engineering and Mathematics (STEM).

Learning Cycle $5 \mathrm{E}$ is one of the developments of the Learning Cycle learning model. This learning model has advantages in increasing motivation to learn because students (students) are actively involved in the learning process, so learning becomes more meaningful [5]. There are five stages in the $5 \mathrm{E}$ Learning Cycle, engagement, exploration, explanation, elaboration, and evaluation [6]. Whereas Science, Technology, Engineering, and Mathematics, also known as STEM, has four learning elements that are well used to improve students' abilities in facing the challenges of the workforce. STEM also has a goal in improving the quality of curriculum and teaching in schools [7]. So with this learning model students are educated in solving problems or difficulties in solving a problem, looking for solutions early. This learning model also has a good impact on student achievement on the topic acid-base [8].

STEM is a learning model related to students' Science Process Skills [9]. SPS is a skill that influences student activities in teaching and learning, both in understanding a process, product and application or understanding a phenomenon that exists in everyday life [10]. So SPS can be used to challenge or face competition in daily life [11], and student achievement can improve [10] [12]. The basis of Science Process Skills consists of skills to observe, classify, predict, measure, infer and communicate [13]. The basics of this skill are the basics interconnected with life [14] noting that in this study, the SPS that is raised in the module is on the indicators of classifying, observing, applying concepts, considering observations, and reading and communicating data.

Thermochemistry is one topic that needs special attention because it is a complicated and abstract [15]. Thermochemistry topics also require good mathematical skills. This is because thermochemistry topics require a good understanding of the stoichiometry section [16]. Several previous studies have not used a specific media for learning chemistry, especially thermochemistry, and digital media-based learning media are also a matter that needs to exist to improve the quality of learning [17].

\section{METHODS}

This research aims to develop a thermochemistry module using the Learning Cycle 5E learning model integrated with STEM. It is equipped with the virtual lab to improve student achievement and to foster science process skill. This research design is a Research and Development (Research and Development) design using the Borg and Gall model [18]. The sample of this study were students and teachers in three state high schools in the city of Kediri, East Java, Indonesia.

The first phase of this research is a preliminary study by distributing questionnaires, interviews, and observations to determine the needs of students in the class and teaching materials and learning models used in teaching and learning in schools. So the 
information obtained will be fulfilled the needs of students in the class. The second stage is the product development modules.

The module developed is a module that has a role in increasing student activities or activeness, so that the science process skills in this module are raised to activate the student's role. Science process skills have a relationship with STEM, so one way is to activate science process skills using a virtual Lab [19]. The virtual lab that emerged in this study uses an existing virtual Lab, chemcollective on thermochemistry. Chemcollective virtual lab is a virtual lab that is like a real laboratory. Problems in the form of experimental activities can be done by each student independently or in groups. This virtual lab presents an activity carried out by students using the knowledge obtained by students by providing problems that students must do [20].

The last stage in this research measures student learning outcomes towards classes that use modules and classes that do not use modules. The results obtained are the average values in thermochemistry material. This stage aims to compare learning outcomes between classes using teaching materials in the School (in the control class) with the modules developed (experimental class).

\section{RESULT AND DISCUSSION}

\section{Analysis Problem of Chemistry Learning}

Before developing a module, it is necessary to analyze the needs of students in the School. This analysis is needed for the continuation of the development of the module. This analysis is obtained by giving questionnaires to students. The questionnaire consists of 8 questions answered by students, and students can provide reasons for the answers that appear. A survey of 36 students to find out what is needed in the chemistry learning process was observation and interviews analysis of student s Problem of Chemistry Learning in Figure 1.

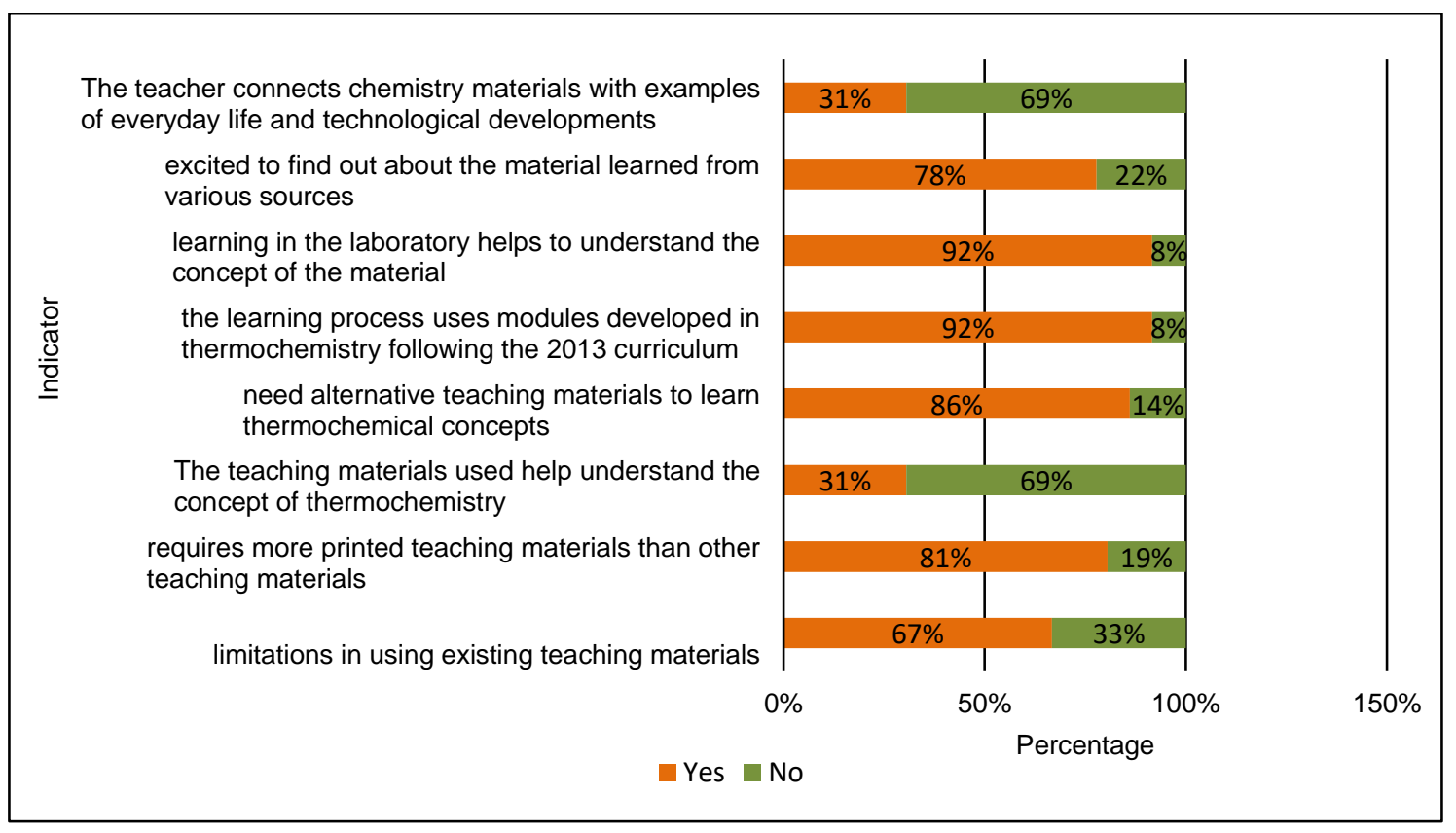

Figure 1. Analysis of chemistry learning on the topic of thermochemistry 
The analysis of the results of the questionnaire can be seen in Figure 1. There are five indicators with eight questions found in the study of the learning process on thermochemistry. The first indicator is an indicator of the availability and need for teaching materials in schools. The first indicator results indicate that students need teaching materials following the 2013 curriculum and can help students understand thermochemical materials. The second indicator is an indicator of the characteristics of the 5E Learning Cycle and STEM learning models. The analysis results of the second indicator show that the books in the School have not implemented the 5E Learning Cycle and STEM learning models. The third indicator is critical thinking skills and the science process skills found in teaching materials at the School. The third indicator results show that the books used in the School have not yet implemented the assessment of critical thinking skills and science process skills. The fourth indicator is an indicator of the material's completeness in the books used at the School. This indicator shows that textbooks used in schools do not yet have complete material, so students get information related to the material from what is conveyed by the teacher.

Observation is deemed necessary by observers because researchers feel that this is one of the initial considerations that cannot be separated from a study. Observations are made by observing teachers and students' activities in the classroom and finding the school environment and facilities. This observation is useful for using learning methods that will be used before developing a product.
In the observation process, students' classroom activities are still not maximized, and students in the learning process do not use books. The lecture method is the method used by the teacher. Students do not fully obtain facilities in the form of books in the School. The teacher explains more with the lecture method to students and questions by dictating or writing them on board. This situation, teacher-centred learning, makes students feel bored quickly and is more passive than student-centred learning [21]. So it needs learning that can suppress student activities to improve student achievement [22].

Interviews were conducted with a chemistry teacher and several students at the School. In interviews with students, it was found that students wanted a handbook that explained various theories and provided activities that could increase student activity and understand the theory by applying thermochemical material that was related to daily activities. This activity will train students to understand thermochemical theories [12] that have been submitted or obtained.

As a result of the discussion with the Chemistry teacher in Kediri, we can find that not all students get handbooks because of the lack of books. Use of media only using PowerPoint, but not all. the use of media requires more costs and time, so the lecture method is more efficient than other methods. thermochemical integrity is not maximum, not more than $60 \%$; and students who have not yet got the completeness are required to improve or do the teacher's assignments. From the results of interviews with students and teachers, this can show that the development of good teaching materials will 
meet student needs. After analyzing research methods, from the student understanding test stage, the student needs analysis, interviews, and observations, it gives a result that the use of modules can help students understand thermochemical topics.

\section{Development of Module}

The module that developed uses model Learning Cycle 5E integrated with STEM in thermochemistry, so high school students can use the module. The curriculum of 2013 and

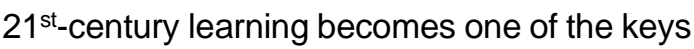
to determining thermochemistry's right method. The use of the 5E Learning Cycle method is a right choice because, in the study, the results showed that completeness in colloidal material with Learning Cycle $5 \mathrm{E}$ has increased and is useful when applied in schools [23]. STEM learning is also useful in understanding electrolysis material in students [24]. And to face the current global challenges, $21^{\text {st }}$ century learning models need to be included in this module. So this research is a research development module of the $5 \mathrm{E}$ Learning Cycle integrated with Science, Technology, Engineering, and Mathematics (STEM).

The developed modules require approximately three weeks with attention to the syllabus used in the School and the 2013 curriculum. Validation was carried out on five experts and two practitioners. The developed module emphasizes the syntax of the $5 \mathrm{E}$ Learning Cycle integrated with STEM, as shown in Table 1.

Table 1. Student activation emphasis on the syntax of the $5 E$ learning cycle integrated with STEM.

\begin{tabular}{ccc}
\hline No & $\begin{array}{c}\text { Fase 5E Learning } \\
\text { Cycle }\end{array}$ & \multicolumn{1}{c}{ Student Activation } \\
\hline 1. & Engagement Phase & $\begin{array}{c}\text { Science Discipline } \\
\text { - Students are divided into groups } \\
\end{array}$ \\
& - Students are given time to discuss the thermochemistry of \\
& the problems presented by the teacher \\
& - Students are given questions about their thoughts from \\
& problems and thermochemistry examples in everyday life
\end{tabular}

2. Exploration Phase

3. Explanation Phase

4. Elaboration Phase
In this activity, students are invited to do a practicum with some of the teacher's equipment.

Science Discipline

- The teacher brings simple natural and pure equipment, such as ice cubes, to inviting students to observe the conditions around the ice cubes if placed in a container.

- Students carry out simple calorimeter experiments using materials that exist in everyday life.

Science Discipline

- The teacher explains the thermochemical material from the knowledge that has been obtained by students regarding thermochemistry

Mathematic Discipline

- Students determine inner energy changes

- Students determine heat

- Students learn the enthalpy of change. Students work out the difficulties and make a graph on the thermochemical questions that have been given. 


\begin{tabular}{|c|c|c|}
\hline No & $\begin{array}{c}\text { Fase 5E Learning } \\
\text { Cycle }\end{array}$ & Student Activation \\
\hline & & $\begin{array}{l}\text { Technology and Engineering Discipline } \\
\text { - Students work in a group in the virtual laboratory by using } \\
\text { chemcollective in thermochemistry } \\
\text { - Students are invited to design a simple calorimeter experiment } \\
\text { method to determine the final temperature of a reaction. }\end{array}$ \\
\hline 5. & Evaluation Phase & $\begin{array}{l}\text { Students are given a test with several questions to be } \\
\text { completed with a teacher's time limit. The results of this test are } \\
\text { the results of the implementation of the method applied. }\end{array}$ \\
\hline
\end{tabular}

Design an Integrated 5E Learning Cycle Module with Science, Technology, Engineering and Mathematics (STEM) in Figure 2. STEM learning influences students' science process skills. This influence occurs in every element of the STEM discipline [9]. STEM learning and student science processes also affect student interest in professional student selection [25] [26]. The use of the four elements of scientific discipline in STEM and science process skills needs to get attention to improve student skills because science process skills influence student learning outcomes.

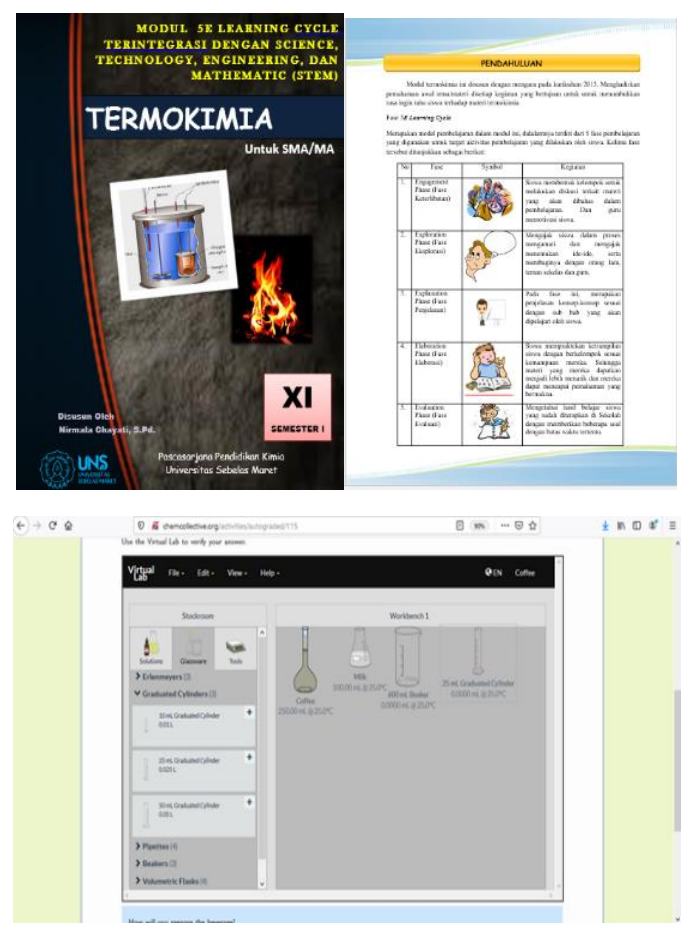

Figure 2. Module Design and Virtual Laboratory of Thermochemistry

\section{Module Trial}

The purpose of product testing is to find out how readability (content and language) and presentation of products that have been developed according to students and teachers in the School. At this stage, three testing times are carried out, namely initial field trials, medium trials (limited) and extensive trials. Trials are given to classes not used for experiments that use modules or do not use modules.

Figure 3 is information from module trials to students and teachers at three trials: initial, intermediate (limited), and extensive field trials. In the initial field test, the content's readability has better results than language and presentation, from Figure 3. The need for improvement in this language can be seen because there are still languages that make students confused, for an example is that there is an image related to thermochemistry. Still, because there is no information relating to sub material or questions that provoke students during the teaching and learning process, student understanding becomes less on target (Figure 5.). The provision of information in an image builds knowledge [27] and can improve students' communication skills [28]. From the result of the teachers' readability questionnaire, on initial fields trial that modules developed, the result was not 
good. Apart from due to incomplete information, writing in symbols and writing, there are still errors. It has come from delta $\mathrm{H}(\Delta \mathrm{H})$, or symbol of temperature $\left({ }^{\circ} \mathrm{C}\right)$.

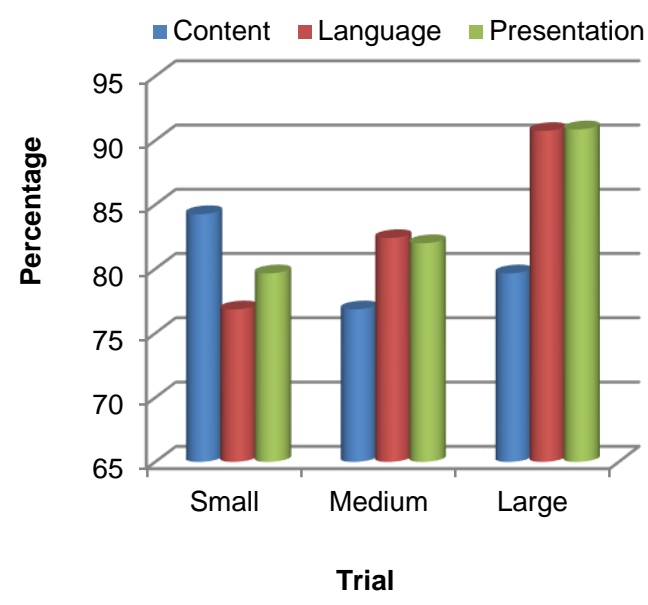

Figure 3. Trial test of Module by Students

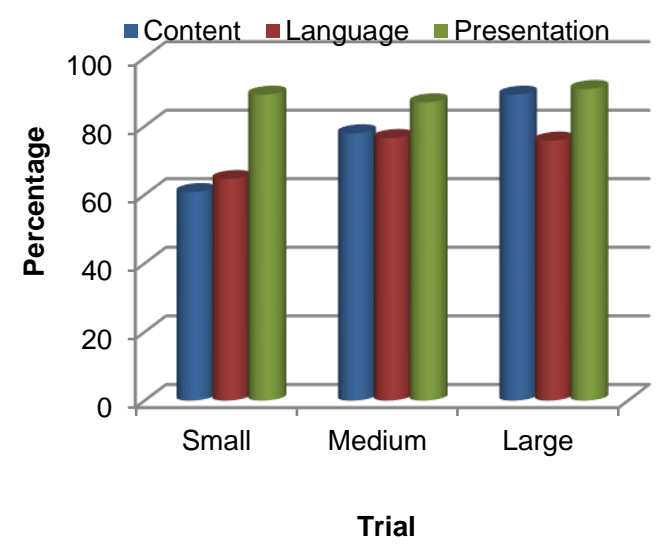

Figure 4. Trial Test of Module by Teachers

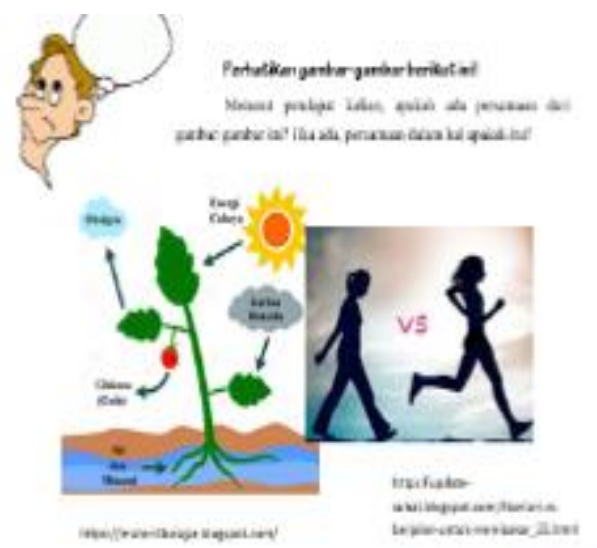

Figure 5. Module Design after revision in the initial trial
Intermediate testing (limited), is an improvement from the initial field trial, from Figure 3 and 4 . It can be seen as an improvement in language and presentation but has decreased in the contents. This is because students' activities in the teaching and learning process of modules developed initially using real laboratory activities. Meanwhile, due to constraints on laboratories in the School and to increase student activity in the use of technology in STEM literacy in thermochemistry material, the virtual laboratory is one of the efforts to increase these activities [29]. Real laboratories and virtual laboratories are student activities that can improve science process skills [30]. Real laboratories and virtual laboratories do not significantly differ in conceptual and factual understanding [31].

Figures 3 and 4 show that the readability (content and language) and the module's presentation have poor results from the start the better after improvements, in extensive trials. In extensive trials, it was also seen that the module had improved teacher and student performance. From the results of this analysis, it can be seen that this module can be used in classroom learning

\section{Science Process Skill}

The purpose of this test is to find out whether students 'process skill skills can grow with the modules that have been developed, and the use of virtual labs can foster students' science process skills-data obtained from students' pretest, post-test, and n-gain.

Figure 6 shows that the average value of $\mathrm{N}$-Gain and post-test values among the experimental classes is higher than the 
control class. These results indicate that the experimental class has a better effect than the control class. Modules developed and equipped with virtual laboratories can foster students' science process skills [32].

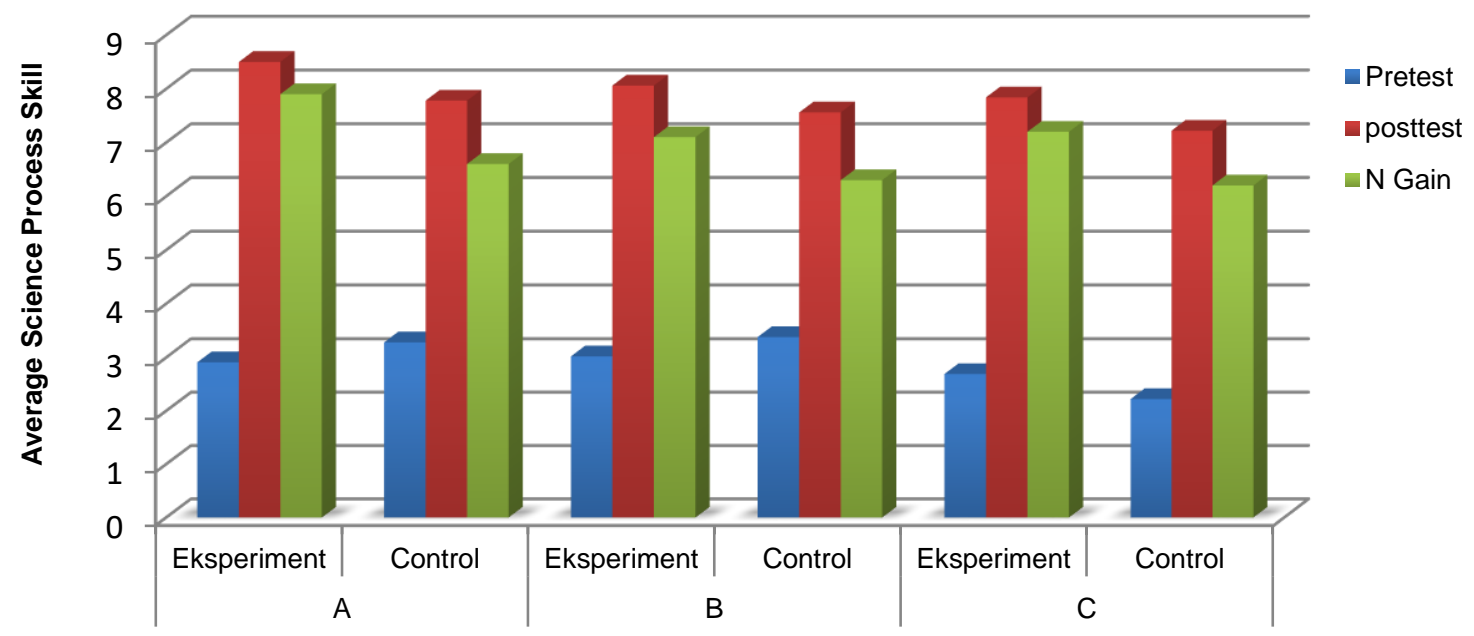

Figure 6. Difference Score between Experiment Classes and Control Class

\section{Student Learning Outcome}

The module test's effectiveness is a test conducted to determine whether the modules developed and used in the experimental class have better results in the classroom than the control class [32]. The experiment class is a class that uses modules as teaching material, while the control class is a class that uses teaching materials from the same School. This test involves three schools by taking two class in each School as a research sample. The number of samples used from this test was 192 students. The class is selected by cluster random sampling method. The learning outcomes of the experimental class and the control class are presented in Table 2.

Table 2. Student Learning Outcome

\begin{tabular}{lcccc}
\hline & \multicolumn{2}{c}{ Experiment } & \multicolumn{2}{c}{ Control } \\
& Completed & Uncompleted & Completed & Uncompleted \\
\hline Total Student & 73 & 23 & 59 & 37 \\
Percentage & 76 & 24 & 62 & 38 \\
\hline
\end{tabular}

Table 2 is the student learning outcome after being given treatment, both classes that use modules and courses that use teaching materials in schools. In the experimental class, 73 students had scores above the minimum criteria score $(\geq 75)$. While in the control class, 59 students already have scores above the minimum criteria score. Simultaneously, the developed modules have succeeded in providing better 
completeness than the teaching materials used in schools. Analysis of student learning outcomes is shown in Table 3, the average thermochemical achievement table.

Table 3. Average Student's Learning Outcomes

\begin{tabular}{ccc}
\hline \multirow{2}{*}{ School } & \multicolumn{2}{c}{ Class } \\
\cline { 2 - 3 } & Experiment & Control \\
\hline A & 79.06 & 76.72 \\
B & 75.78 & 73.90 \\
C & 74.84 & 70.31 \\
\hline
\end{tabular}

Table 3 is a table of the average student learning outcomes in the experimental class and the control class in the three schools. These results indicate that classes using this module have better learning outcomes. This means that students' understanding of using modules has better results than classes that do not use modules. Thus the module can improve students' thermochemistry learning outcomes.

\section{CONCLUSION}

The results of the research conducted found that: students need teaching materials that can encourage student achievement in the $21^{\text {st-century teaching and learning process }}$ in thermochemical material; the validity of the module declared valid by the weight expert $(\mathrm{v}$ $=0.89$ ); The module can foster science process skills and the module developed shows effective results seen from learning outcomes in thermochemical material.

\section{REFERENCES}

[1] G. Rahmawati, "Buku teks pelajaran sebagai sumber belajar siswa di perpustakaan sekolah di SMAN 3
Bandung". Edulib, vol. 5, no. 1, pp. 102-113, 2015.

DOI:10.17509/edulib.v5i1.2307

[2] Hs. Lasa, "Penyusunan Artikel dan Publikasi Sekunder", Tangerang Selatan: Universitas Terbuka, 2014 ISBN 9789790117594

[3] W. Maba, "Teacher's perception on the implementation of the assessment process in 2013 curriculum." International Journal of Social Sciences and Humanities, vol. 1, no 2, pp. 1-9, 2017. DOI:10.29332/ijssh.v1n2.26

[4] F. S. Irwansyah, Y. M. Yusuf, I. Farida, and M. A. Ramdhani, "Augmented reality $(A R)$ technology on the android operating system in chemistry learning." In IOP conference series: Materials science and engineering 288(1), p. 012068, 2018.

DOI:10.1088/1757-899X/288/1/012068

[5] A. Shoimin, 68 Model Pembelajaran Inovatif dalam kurikulum 2013, Yogyakarta: Ar-Ruzz Media, 2014 ISBN 978-602-313-017-7

[6] R. W Bybee, "The BSCS 5E instructional model and 21st Century Skills", A commissioned paper prepared for a workshop exploring the intersection of science education and the development of 21st-century skills, 2009.

ISBN: 978-1941316009

[7] L. D. English, "STEM education K-12: Perspectives on integration." International Journal of STEM education, vol. 3, no.1, p. 3, 2016. DOI:10.1186/s40594-016-0036-1

[8] D. P. Sari and R. M. Dewi, "Pengaruh Ketrampilan Berpikir Kritis dan Berpikir Kreatif Terhadap Hasil Belajar Mata Pelajaran Ekonomi Kelas X IPS di MAN Mojosari" Jurnal Pendidikan Ekonomi, vol. 5, no. 1, pp. 1-8, 2017. DOI:10.26740/jupe.v5n1.p\%25p 
[9] F. Zorlu and Y. Zorlu, "Comparison of Science Process Skill with STEM career interest of Middle School Student", Universal Journal of Educational Research, vol. 12, no 5, pp. 2117-2124, 2017

DOI:10.13189/UJER.2017.051201

[10] A. Lepiyanto, "Analisis Ketrampilan Proses Sains pada Pembelajaran Berbasis Praktikum", Bioedukasi: Jurnal Pendidikan Biologi, vol 2, no 5, pp. 156-161, 2014.

DOI:10.24127/bioedukasi.v5i2.795

[11] M. C. Li, and C. C. Tsai, "Game-based learning in science education: A review of relevant research." Journal of Science Education and Technology, vol. 22, no. 6, pp. 877-898, 2013.

DOI:10.1007\%252Fs10956-013-9436-x

[12] W. Arifin, L. Latisma, and B. Oktavia, "Development Module of Chemistry Learning Based on Chemo-entrepreneurship Oriented", vol 7, no 1, pp. 5156, 2018

Proceeding

[13] S. Yamtinah, M. Masykuri, Ashadi, and A. S. Shidiq, "An Analysis of Students' Science Process Skills in Hydrolysis Subject Matter Using Testlet Instrument" ICTTE, 158, pp. 101-110, 2017.

DOI: 10.2991/ictte-17.2017.36

[14] Juhji, "Peningkatan Ketrampilan Proses Sains Melalui Pendekatan Inkuiri Terbimbing", Jurnal Penelitian dan Pembelajaran IPA. vol 1, no. 2, pp. 58-70, 2016.

DOI: 10.30870/jppi.v2i1.419

[15] Aswita, Rusman and R. F. I. Rahmayani, "Identifikasi Kesulitan Siswa dalam Memahami Materi Termokimia dengan Menggunakan Three-Tier Multiple Choice Diagnostic Instrument di Kelas XI MIA 5 MAN Model Banda Aceh", Jurnal IImiah
Mahasiswa Pendidikan Kimia (JIMPK), vol. 2, no. 1, pp. 35-44, 2016.

Google Scholar

[16] Zakiyah, S. Ibnu, and Subandi, "Analisis Dampak Kesulitan Siswa pada Materi Stoikiometri terhadap Hasil Belajar Termokimia", Jurnal Kimia dan Pendidikan, vol. 3, no 1, pp. 119-134, 2018.

DOI:10.30870/educhemia.v3i1.1784

[17] A. C. Sugiarti, S. Suyatno, and I. G. M. Sanjaya, "The Development of Learning Material using Learning Cycle 5E Model Based STEM to Improve Students' Learning Outcomes in Thermochemistry", International Conference on Science Education, vol 1006, pp. 1-7, 2018.

DOI:10.1088/1742-6596/1006/1/012039

[18] W.R Borg, and M. D. Gall, Educational Reseach: An Introduction, New York: Longman, 2012. ISBN: 9780321081896

[19] Gunawan, A. Harjono, Hermansyah, and L. Herayanti, "Guided Inquiry Model Through Virtual Laboratory to Enhance Students' Science Process Skills On Heat Concept", Cakrawala Pendidikan, vol. 38, no. 2, 2019.

DOI:10.21831/cp.v38i2.23345

[20] D. Yaron, M. Karabinos, D. Lange, J. G. Greeno, and G. Leinhardt, "The ChemCollective-Virtual Labs for Introductory Chemistry Courses", Science Prize for Online Resources in Education, vol 328, pp. 584-585, 2010.

DOI:10.1126/science.1182435

[21] S. Petersen, K. and Hack, "The thermo-chemistry library ChemApp and its applications". International journal of materials research, vol. 98, no. 10, pp. 935-945, 2007.

DOI:10.3139/146.101551 
[22] D. A. Sari, I. Iswendi, and B. Bayharti, "Making Chemical Snakes and ladders Game as Learning Media on Hydrocarbon Compound Material for Senior High School". International Journal of Progressive Sciences and Technologies, vol. 21, no. 1, pp. 115122, 2020.

Google Scholar

[23] M. P. Chen, Y. T. Wong, and L. C. Wang, "Effects of type of exploratory strategy and prior knowledge on middle school students' learning of chemical formulas from a $3 \mathrm{D}$ roleplaying game". Educational Technology Research and Development, vol. 62, no. 2, pp. 163185, 2014

DOI:10.1007\%2Fs11423-013-9324-3

[24] N. H. D. Huri and M. Karpudewan "Evaluating the Effectiveness of Integrated STEM-lab Activities in Improving Secondary School Student: Understanding of Electrolysis." Chem. Edu. Res Prac, vol. 20, pp 495-508, 2019.

DOI:10.1039/C9RP00021F

[25] L. N. Calkins and A. Welki, "Factors that influence choice of major: Why some students never consider economics", International Journal of Science Economics, vol 33, no 8, pp 547-564, 2006.

DOI:10.1108/03068290610678707

[26] W. L. Kuechler, A. McLeod, and M. G. Simkin, "Wy don't more students major in IS?", Decision Science Journal of Inovation Education, vol. 7, no 2, pp 463-488, 2009.

DOI:10.1111/j.1540-4609.2009.00231.x
[27] S. Liao and E. Chao, "Intention to adopt knowledge through virtul communities: posters vs lukers", Online Information review, vo.I 36, no. 3, pp. 442-461, 2012.

DOI:10.1108/14684521211241440

[28] M. P. Kelsch and A. B. Werremeyer, "Poster Project to Emphasize Public Health in The Pharmacy Curriculum", American Journal of Pharmaceutical Education, vol. 75, no. 1, pp. 1-8, 2011. DOI:10.5688/ajpe7512

[29] S. S. Maulidah and E. C. Prima, "Using Physics Education Technology as Virtual Laboratory in Learning Waves and Sounds", Journal of Science Learning, vol. 3, no. 1, pp. 116-121, 2018. DOI:10.17509/jsl.v1i3.11797

[30] N. Sulistiowati, L. Yuanita, and Wasis, "Perbedaan Penggunaan Laboratorium Real dan Laboratorium Virtual pada Ketrampilan Proses Sains dan Hasil Belajar Siswa Materi Asam Basa", Jurnal Penelitian Pendidikan Sains, vol 3, no. 2, pp. 191-197, 2013. DOI:10.26740/jpps.v2n2.p191-197

[31] I. Hawkins and A. J. Phelps, "Virtual Laboratory vs. Tradisional Laboratory: Which is More Effective for Teaching Electrochemistry?", Chemistry Education Research and Practice, vol. 4, No. 14, pp. 516-523, 2013.

DOI:10.1039/C3RP00070B

[32] R. M. Situmorang, Muhibbuddin, and Khairil, "Penerapan Model Pembelajaran Problem Learning unuk Meningkatkan Hasil Belajar Siswa pada Materi Sistem Ekskresi Manusia", Jurnal EduBio Tropika, vol. 3, no. 2, pp. 5197, 2015.

Google Scholar 